\title{
Serum Magnesium Level in Infants and Children with Hepatic Diseases
}

\author{
AKIO KOBAYASHI and KAZUO SHIRAKI \\ From the Department of Paediatrics, Unversity of Tokyo, Tokyo, Japan
}

Congenital biliary atresia (CBA) and neonatal 'hepatitis' are the main causes of obstructive jaundice during infancy, and it is well recognized how difficult it often is to distinguish one from the other. The prognosis of neonatal hepatitis for complete recovery is good, while that of CBA is poor. Yet to differentiate CBA from neonatal hepatitis is important because in CBA surgery may be the treatment of choice.

Stutzman and Amatuzio (1953) stressed the importance of hepatic cirrhosis as a cause of hypomagnesaemia. Since then, additional information on hypomagnesaemia in this condition has been provided by Flink (1956), Flink, McCollister, Prasad, Melby, and Doe (1957), Wacker and Vallee (1958), and Hänze (1962). As the main pathological lesion of the liver in prolonged cases of CBA is biliary cirrhosis, a low serum magnesium level is presumed to reflect the biliary cirrhosis.

The purpose of this communication is to report the serum magnesium level and its relation to liver function tests in CBA and neonatal hepatitis, and to discuss its use in differentiating these two conditions. Serum magnesium levels in other hepatic diseases are also reported.

\section{Materials and Methods}

The subjects were 11 infants with surgically noncorrectable type of CBA, 14 infants with neonatal hepatitis, 2 infants with choledochal cyst; 5 children with infective hepatitis; 3 children with serum hepatitis; 1 child with drug-induced hepatitis; 3 children with chronic hepatitis, 2 children with cirrhosis of the liver; 3 children with Wilson's disease; and 2 infants and 1 child with hepatoblastoma.

All patients with CBA had exploratory laparotomy. Diagnosis of neonatal hepatitis was on clinical and laboratory grounds, excluding other diseases causing obstructive jaundice during infancy. In practice, the demonstration of bile flow by duodenal intubation, the absence of radiographic signs of choledochal cyst, and

Received December 20. 1966. the fact on follow-up of a favourable clinical course were the chief pointers to a diagnosis of neonatal hepatitis.

Blood samples were taken from the patients fasting. After immediate separation of the serum by centrifugation, the samples were kept frozen at $-20^{\circ} \mathrm{C}$.

Serum magnesium concentrations were determined in duplicate by the fluorometric method of Schachter (1961). Reagent 1 was $0 \cdot 1 \mathrm{M}$ Tris buffer of $p \mathrm{H} \mathrm{7.0}$ and reagent $20.0025 \mathrm{M}$ 8-hydroxy-5-quinolinesulphonate in $0.1 \mathrm{M}$ Tris buffer of $p \mathrm{H} 7 \cdot 0$. For each estimation, $5.0 \mathrm{ml}$. reagents 1 and 2 were placed into separate test tubes. An aliquot of $0.1 \mathrm{ml}$. serum was added to each tube, mixed and, decanted into cuvettes.

Fluorescence was measured with Multiplier Fluorescence Meter Model 540 (Photovolt), using a B Hg-1 Filter (wave length, 365 millimicrons) for the primary filter, and B 520 Filter (wave band, 480-580 millimicrons) for the secondary one. The fluorescence intensity in reagent 1 was subtracted as a blank correction (F2-F1). In addition, reagent blanks containing water in place of serum were tested similarly $\left(F 1^{\prime}, F 2^{\prime}\right)$, and the net fluorescence was also subtracted as a blank correction ((F2-F1)$\left.\left(F 2^{\prime}-F 1^{\prime}\right)\right)$. The final value for each serum sample was compared with the corresponding value observed with a reference standard tested similarly. Mean recovery by this method was $96 \cdot 8 \%$, with a range of $96 \cdot 2$ to $98 \cdot 0 \%$. Normal levels were somewhat higher than those reported by others. We have found that this difference results from the use of filters to isolate the desired exciting and fluorescent wave bands rather than spectrofluorometry.

\section{Results}

Serum magnesium level of control group. Serum magnesium level was determined in 78 healthy infants and children randomly selected. The mean value from the age of 2 to 11 months was $2.26 \mathrm{mEq} / \mathrm{l}$. (SD 0.15), with a range of 1.95 to $2.52 \mathrm{mEq} / \mathrm{l}$. In the group from 1 to 6 years, the value was $2 \cdot 25 \mathrm{mEq} / \mathrm{l}$. (SD $0 \cdot 16$ ), with a range of $1 \cdot 97$ to $2 \cdot 53$, and in the group above 6 years, $2 \cdot 16$ $\mathrm{mEq} / \mathrm{l}$. (SD $0 \cdot 17$ ), with a range of 1.82 to 2.63 (Fig. 1). 


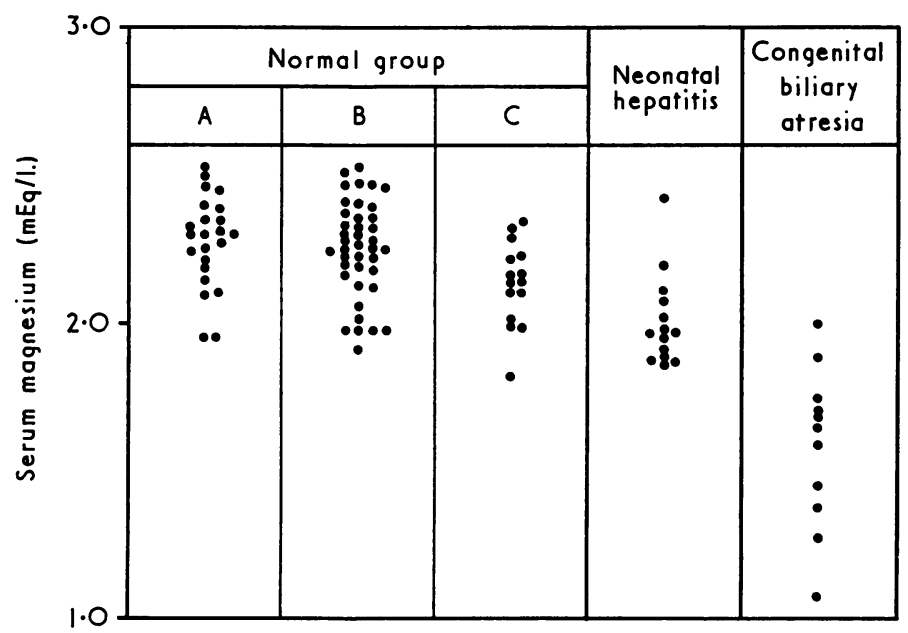

FIG. 1.-Distribution of serum magnesium level in normal $(A=2-11$ months; $B=1-5$ years; $C=6-15$ years) group, neonatal hepatitis, and congenital biliary atresia.

Serum magnesium level in various hepatic diseases. The distribution of serum magnesium level in CBA and neonatal hepatitis is shown as a scattergram in Fig. 1. In CBA serum magnesium level was reduced, with the mean value of 1.60 $\mathrm{mEq} / \mathrm{l}$. (SD 0.26), which was significantly lower than normal $(p<0 \cdot 01)$. On the other hand, in neonatal hepatitis the reduction of serum magnesium level was less than in CBA, but still significantly lower than normal $(p<0.01)$ (mean $2 \cdot 01 \mathrm{mEq} / 1$. and $\mathrm{SD} 0 \cdot 14)$. The difference between the serum magnesium level in CBA and that in neonatal hepatitis was statistically significant $(\mathrm{p}<0.01)$. The serum magnesium level in other hepatic diseases is summarized in the Table; a variable decrease was found.

TABLE

Serum Magnesium Level in Various Hepatic Diseases

\begin{tabular}{|c|c|c|c|c|}
\hline & & $\begin{array}{l}\text { No. of } \\
\text { Cases }\end{array}$ & $\underset{(\mathrm{mEq} / \mathrm{l} .)}{\text { Mean }}$ & $\underset{(\mathrm{mEq} / \mathrm{l} .)}{\text { Range }}$ \\
\hline $\begin{array}{l}\text { Congenital biliary atresia } \\
\text { Neonatal hepatitis .. } \\
\text { Choledochal cyst .. } \\
\text { Infectious hepatitis } \\
\text { Serum hepatitis ... } \\
\text { Drug-induced hepatitis } \\
\text { Chronic hepatitis } \\
\text { Hepatic cirrhosis .. } \\
\text { Wilson's disease .. } \\
\text { Hepatoblastoma ... }\end{array}$ & \begin{tabular}{l|} 
\\
$\cdots$ \\
$\cdots$ \\
$\cdots$ \\
$\cdots$ \\
$\cdots$ \\
$\cdots$ \\
$\cdots$
\end{tabular} & $\begin{array}{r}11 \\
14 \\
2 \\
5 \\
3 \\
1 \\
3 \\
2 \\
3 \\
3\end{array}$ & $\begin{array}{l}1 \cdot 60 \\
2 \cdot 01 \\
2 \cdot 01 \\
1 \cdot 80 \\
1 \cdot 81 \\
1 \cdot 69 \\
1 \cdot 95 \\
1 \cdot 84 \\
1 \cdot 95 \\
2 \cdot 34\end{array}$ & $\begin{array}{l}1 \cdot 10-2 \cdot 01 \\
1 \cdot 85-2 \cdot 42 \\
1 \cdot 89-2 \cdot 13 \\
1 \cdot 50-2 \cdot 07 \\
1 \cdot 62-1 \cdot 98 \\
1 \cdot 85-2 \cdot 00 \\
1 \cdot 79-1 \cdot 89 \\
1 \cdot 70-2 \cdot 16 \\
1 \cdot 95-2 \cdot 67\end{array}$ \\
\hline
\end{tabular}

Relations of serum magnesium level to age and liver function tests. Serum magnesium level showed a tendency to decrease with the age of the patients in CBA, but not in neonatal hepatitis (Fig. 2). One case with CBA showed a very low level even at the age of 2 months. In CBA serum magnesium was directly related to the albumin/ $\gamma$-globulin ratio $(r=0.85)$ (Fig. 3) and to the serum cholesterol level $(r=0.82)$ (Fig. 4), and inversely related to total serum bilirubin $(\mathbf{r}=$ -0.91 ) (Fig. 5). By contrast, serum magnesium level was not related to serum alkaline phosphatase, SGOT, SGPT, thymol turbidity test, or zinc sulphate test.

In neonatal hepatitis, the serum magnesium level was not related to the age of the patient, or to the liver function tests listed (Fig. 2-5).

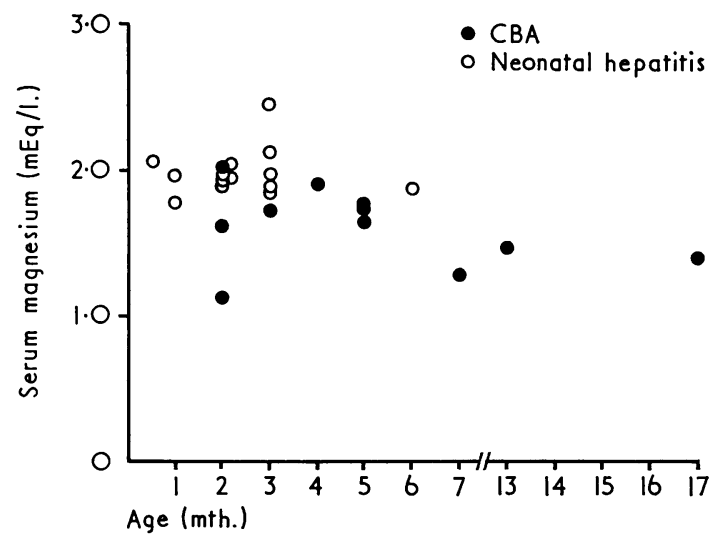

FIG. 2.-Relation between serum magnesium level and the age of patients with $C B A$ and neonatal hepatitis. 


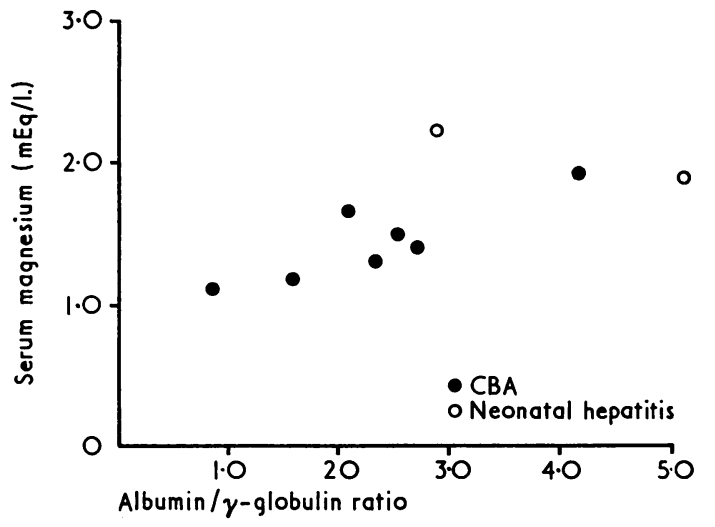

FIG. 3.-Relation between serum magnesium level and serum albumin $/ \gamma$-globulin ratio in $C B A$ and in neonatal hepatitis.

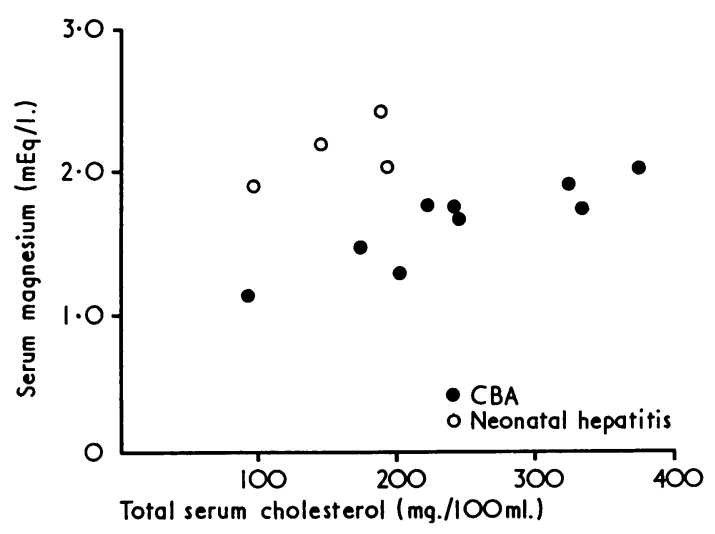

FIG. 4.-Relation between serum magnesium level and total serum cholesterol in CBA and in neonatal hepatitis.

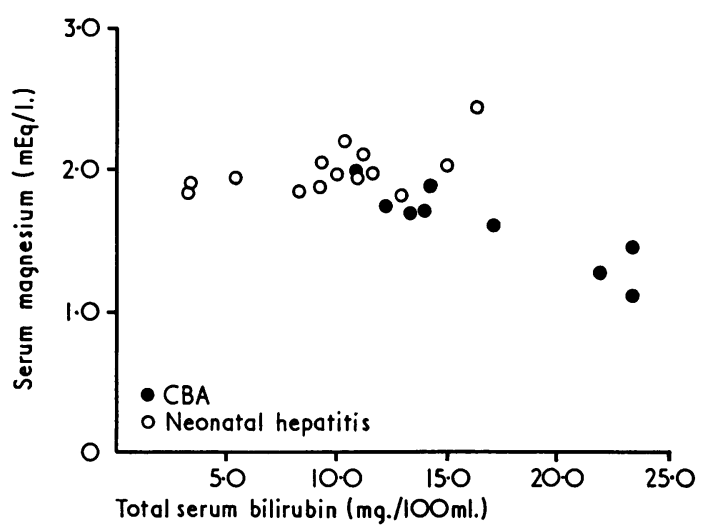

FIG. 5.-Relation between serum magnesium and total serum bilirubin level in $C B A$ and in neonatal hepatitis.

\section{Discussion}

We have found serum magnesium level to be greatly reduced in CBA, but to a lesser extent in neonatal hepatitis. Serum magnesium levels may, therefore, be useful in differentiating CBA from neonatal hepatitis, and from other hepatic diseases in which the reduction in serum magnesium was also slight. In CBA the serum magnesium level was directly related with the albumin $/ \gamma$-globulin ratio, and with total serum cholesterol, which is known to decrease in the terminal stage of hepatic cirrhosis; while it, was inversely related to the total bilirubin level. Serum magnesium showed a tendency to decrease with the age of the patients in CBA. These results suggest that the degree of hypomagnesaemia parallels the severity of the liver lesion (an inference which is, however, not compatible with the observations of Wacker and Vallee (1958)).

The mechanism of hypomagnesaemia in CBA is poorly understood. According to Haywood and Höber (Harris, 1960) the cirrhotic liver is able to store both magnesium and potassium. Hänze (1962) postulated that hypomagnesaemia in hepatic cirrhosis was due to an increase in $\gamma$-globulin, unable to bind magnesium, at the expense of a decrease in magnesium-binding albumin. Recently, Mader and Iseri (1955), Milne, Muehrcke, and Aird (1957), and Horton and Biglieri (1962) reported that aldosterone increased renal excretion of magnesium. Coppage, Island, Cooner, and Liddle (1962) demonstrated that the rate of removal of labelled aldosterone from the plasma was diminished in hepatic cirrhosis. Patients with CBA are probably to be regarded as in a state of secondary hyperaldosteronism because of decreased inactivation of aldosterone by the liver. Hypomagnesaemia in CBA may therefore be partly explained as due to secondary hyperaldosteronism. In addition, since Meintzer and Steenbock (1955) demonstrated that in the rat vitamin $\mathrm{D}$ increased gastro-intestinal absorption of magnesium, vitamin $D$ deficiency, which is not uncommon in CBA because of the lack of bile in the intestine, may play a part in the development of hypomagnesaemia.

\section{Summary}

Serum magnesium level in infants and children with various hepatic diseases was found to be generally reduced. It was greatly reduced in congenital biliary atresia, but to a lesser extent in other hepatic diseases including neonatal hepatitis. In congenital biliary atresia the degree of hypomagnesaemia was dependent on the severity of the liver lesions, for the serum magnesium level was directly related to the albumin $/ \gamma$-globulin ratio and 
the total cholesterol, and was inversely related to the serum bilirubin level. It is concluded that the serum magnesium level is of use in differentiating congenital biliary atresia from neonatal hepatitis.

\section{REFERENCES}

Coppage, W. S., Island, D. P., Cooner, A. E., and Liddle, G. W. (1962). The metabolism of aldosterone in normal subjects and in patients with hepatic cirrhosis. $\mathcal{F}$. clin. Invest., 41, 1672.

Flink, E. B. (1956). Magnesium deficiency syndrome in man. $f$. Amer. med. Ass., 160, 1406.

-, McCollister, R., Prasad, A. S., Melby, J. C., and Doe, R. P. (1957). Evidences for clinical magnesium deficiency. Ann. intern. Med., 47, 956.

Hänze, S. (1962). Der Magnesiumstoffwechsel. G. Thieme, Stuttgart.
Harris, E. J. (1960). Transport and Accumulation in Biological Systems, 2nd ed. Butterworth, London.

Horton, R., and Biglieri, E. G. (1962). Effect of aldosterone on the metabolism of magnesium. F. clin. Endocr., 22, 1187.

Mader, I. J., and Iseri, L. T. (1955). Spontaneous hypopotassemia, hypomagnesemia, alkalosis and tetany due to hypersecretion of corticosterone-like mineralocorticoid. Amer. f. Med., 19, 976.

Meintzer, R. B., and Steenbock, H. (1955). Vitamin D and magnesium absorption. f. Nutr., 56, 285.

Milne, M. D., Muehrcke, R. C., and Aird, I. (1957). Primary aldosteronism. Quart. F. Med., 26, 317.

Schachter, D. (1961). Fluorometric estimation of magnesium with 8-hydroxy-5-quinolinesulfonate. F. Lab. clin. Med., 58, 495.

Stutzman, F. L., and Amatuzio, D. S. (1953). Blood serum magnesium in portal cirrhosis and diabetes mellitus. ibid., 41, 215.

Wacker, W. E. C., and Vallee, B. L. (1958). Magnesium metabolism. New Engl. f. Med., 259, 431. 